\title{
Morphological variation in an anopthalmic specimen of Sperata seenghala (Sykes, 1839) from Brahmaputra River, Assam, India
}

\author{
Jyotish Barman $^{1 *}$, A.K. Jaiswar ${ }^{1}$, S.K. Chakraborty ${ }^{1}$, B.K. Bhattacharjya ${ }^{2}$ and Gopal- \\ krishna ${ }^{1}$ \\ ${ }^{1}$ Indian Council of Agricultural Research (ICAR), Central Institute of Fisheries Education (Deemed University), \\ Panchmarg, Off Yari road, Andheri (W), Mumbai - 400061 (Maharastra), INDIA \\ ${ }^{2}$ ICAR-Central Inland Fisheries Research Institute, Guwahati Regional Centre, Housefed Complex, Dispur- 781006 \\ (Assam), INDIA \\ *Corresponding author. E-mail: jyotish5@gmail.com
}

Received: November 2, 2015; Revised received: March 17, 2016; Accepted: May 30, 2016

Abstract: The present investigation reports the variation observed in morphological traits of an anopthalmic specimen of Sperata seenghala (Sykes, 1839) (168.9 mm in standard length) from Assam. Thirty morphometric and six meristic characters of the abnormal specimen were studied and compared with normal specimens to observe variation in the morpho-meristic traits, if any. The proportionate pre-pectoral length $(28.5 \mathrm{~mm})$, length of dorsal fin base $(15.0 \mathrm{~mm})$, pelvic fin length $(15.5 \mathrm{~mm})$, distance between urino-genital openings and anal fin base $(14.0 \mathrm{~mm})$ and body depth at pectoral fin base $(12.0 \mathrm{~mm})$ of the abnormal specimen was found to be higher compared to that of the normal specimens $(23.8-26.5$ $\mathrm{mm} ; 12.2-14.1 \mathrm{~mm} ; 11.1-14.7 \mathrm{~mm} ; 10.9-12.4 \mathrm{~mm}$ and $8.9-9.9 \mathrm{~mm}$, respectively); while the dorsal to adipose distance $(12.8 \mathrm{~mm})$ and body width at cleithrum $(41.5 \mathrm{~mm})$ was lower than the normal specimens $(13.7-16.7 \mathrm{~mm}$ and $44.0-50.0 \mathrm{~mm}$, respectively). No marked variation was observed in the meristic characters. Pollution due to urban runoff, sewage discharge and oil spill from inland water transport facilities adversely affecting the river water quality could be the reason for such deformity. The overall growth performance of the fish does not seem to be affected by these anomalies.

Keywords: Anopthalmia, Assam, Environmental stress, Morpho-meristic traits, Sperata seenghala

\section{INTRODUCTION}

Anopthalmia (the congenital absence of one or both eyes) in fish have been reported by many authors. A compiled bibliography of 1499 papers on fish anomalies described 63 papers on eye abnormalities (Tave and Handwerker, 1998). Later on some more reports have been published on morphological anomalies in fishes (Kruitwagen et al., 2006; Tave et al., 2011; Saha and Saha, 2013; Barman et al., 2014). Nutritional deficiency, temperature variations, low dissolved oxygen, high carbon dioxide concentration in water, parasitic infection are some factors believed to be cause of such anomalies in fish (Turner and Farley, 1971; Anonymous, 1996; Cahu et al., 2003; Cunningham et al., 2005; Martens et al., 2006). Besides, pollutants like chlorinated hydrocarbons, organophosphates, pesticides, heavy metals as well as developmental error and injury are also responsible for deformation in fishes (Weis and Weis, 1989; Gupta et al., 2000; Subba, 2008; Lin Sun et al., 2009). Abnormalities in catfish are least reported and those available are mostly related to skeletal deformity (Sarkar and Kapoor, 1956; Jesu et al., 2004; Nagarajan, 2012). Barman et al. (2014) also reported a case of anopthalmia in the striped catfish Mystus tengara from Assam. The South Asian bagrid catfish of genus Sperata comprises a group of four species viz. Sperata seenghala, S. aor, $S$. acicularis and $S$. aorella distributed from Pakistan to Myanmar. All species of this genus are commercially important food fishes and among the largest catfishes of South Asia (Ferraris and Runge, 1999). Among these, Sperata seenghala, S. aor and S. aorella are found in the Ganga River basin, of which S. seenghala is widely distributed in the Ganges and Indus river drainages, and also occurs in several major rivers in peninsular India at least as far south as the Krishna River (Ferraris and Runge, 1999). This fish species is commonly landed from rivers of Assam. The present communication is an attempt to report the case of anophthalmia in S. seenghala collected from Brahmaputra River, Assam along with a comparative note on the morphological differences observed.

\section{MATERIALS AND METHODS}

The deformed specimen of S. seenghala (lacking right eye) was collected on $10^{\text {th }}$ December, 2013 from Brahmaputra River near Uzanbazaar ghat (Guwahati), Assam, India, during routine collection of samples for taxonomic evaluation of the genus Sperata. The speci- 
men measuring $168.9 \mathrm{~mm}$ in standard length is preserved in the museum at Central Institute of Fisheries Education (CIFE), Mumbai, India (CIFE/FRM/MUS/ Ss-11). Ten normal specimens of the same species were also collected from the same site on the same day for observation of morphological features (Fig. 1). Thirty six morphological characters (30 morphometric and 6 meristic) were recorded for comparison. Measurements were made point to point on the left side wherever possible with a digital dial vernier caliper to the nearest $0.1 \mathrm{~mm}$. Standard lengths of specimen above $200 \mathrm{~mm}$ were measured using a measuring tape. Subunits of the head are presented as proportions of head length (HL). Head length and measurements of body parts are given as proportions of standard length (SL). For the normal specimen the data are given in range (Table 1). Gillrakers count on the first left branchial arch was taken only for the normal specimen. Methods for counting gillrakers follow Roberts (1992). The inter-orbital distance of the abnormal specimen could not be measured for obvious reason and the gillraker count was also not taken to avoid damage to the specimen. Identification of the species as well as counts and measurements were taken by following the key of Ferraris and Runge (1999).

\section{RESULTS AND DISCUSSION}

The biometric features of the abnormal and normal specimens are presented in table-1. The dorsal fin of abnormal specimen has 1 spinelet, 1 stout spine and 7 branched rays. Pelvic fin with 1 unbranched and 5 branched rays. Pectoral fin has 9 branched rays with a stout spine. Anal fin possess 3 unbranched and 9 branched rays. Caudal fin is deeply forked and both upper and lower lobes have1 unbranched and 7 branched rays.

The normal specimens have 1 spinelet, 1 stout spine and dorsal fin with 7 branched rays. Pelvic fin has 1 unbranched and 5 branched ray. Pectoral fin has 8 or 9 branched rays. The unbranched and branched rays of anal fin ranged between 3-4 and 9-10, respectively. While, both lobes of the caudal fin bear 1 unbranched ray, the upper and lower lobes has 7 and 7/8 branched rays, respectively. Gillraker count for the normal specimens ranged between 14 and 15, with 3 - 4 in the upper limb and $11-12$ in the lower limb. The meristic count of both abnormal and normal specimens does not differ from the report given by Ferraris and Runge (1999).

Several authors have postulated different factors re-

Table 1. Biometric data of S. seenghala (in $\mathrm{mm}$ ).

\begin{tabular}{|c|c|c|c|}
\hline & \multirow{2}{*}{$\begin{array}{l}\text { Abnormal speci- } \\
\text { men }\end{array}$} & \multicolumn{2}{|c|}{ Normal specimen $(\mathbf{n}=10)$} \\
\hline & & Range & Mean \pm SD \\
\hline Standard length (SL) & 168.9 & $173.0-254.0$ & $204.2 \pm 27.6$ \\
\hline \multicolumn{4}{|l|}{ In $\% \mathrm{SL}$} \\
\hline Pre dorsal length & 43.1 & $39.9-43.3$ & $41.5 \pm 1.4$ \\
\hline Pre pelvic length & 53.8 & $51.2-54.6$ & $52.5 \pm 1.1$ \\
\hline Pre anal length & 72.6 & $69.5-75.1$ & $72.5 \pm 1.9$ \\
\hline Pre pectoral length & 28.5 & $23.8-26.5$ & $25.4 \pm 0.9$ \\
\hline Dorsal fin length & 25.3 & $18.7-24.8$ & $22.0 \pm 2.3$ \\
\hline Length of dorsal fin base & 15.0 & $12.2-14.1$ & $13.0 \pm 0.7$ \\
\hline length of dorsal spine & 20.9 & $15.5-21.0$ & $18.5 \pm 2.2$ \\
\hline length of anal fin base & 9.8 & $8.7-10.4$ & $9.4 \pm 0.6$ \\
\hline Anal fin height & 16.3 & $12.5-16.3$ & $14.7 \pm 1.3$ \\
\hline Pelvic fin length & 15.5 & $11.1-14.7$ & $13.2 \pm 1.2$ \\
\hline Pectoral fin length & 15.1 & $12.6-17.8$ & $14.3 \pm 1.7$ \\
\hline Pectoral spine length & 12.6 & $11.0-13.9$ & $12.4 \pm 1.5$ \\
\hline Caudal peduncle length & 15.0 & $14.1-16.1$ & $15.4 \pm 0.6$ \\
\hline Caudal peduncle depth & 6.0 & $5.2-6.2$ & $5.6 \pm 0.3$ \\
\hline Adipose maximum height & 4.4 & $3.0-4.1$ & $3.7 \pm 0.4$ \\
\hline length of adipose fin base & 15.1 & $13.2-15.6$ & $14.3 \pm 0.7$ \\
\hline Pre adipose length & 69.5 & $68.4-71.8$ & $70.2 \pm 1.0$ \\
\hline Dorsal to adipose distance & 12.8 & $13.7-16.7$ & $15.2 \pm 0.9$ \\
\hline Head Length (HL) & 30.7 & $26.6-29.8$ & $28.2 \pm 1.2$ \\
\hline Distance between urino-genital opening and anal fin base & 14.0 & $10.9-12.4$ & $12.0 \pm 0.5$ \\
\hline Body depth at pectoral fin base & 12.0 & $8.9-9.9$ & $9.7 \pm 0.3$ \\
\hline \multicolumn{4}{|l|}{ In $\% \mathrm{HL}$} \\
\hline Snout length & 28.7 & $26.5-31.0$ & $28.4 \pm 1.3$ \\
\hline Maxillary barbel length & 245.2 & $209.3-266.0$ & $232.0 \pm 16.9$ \\
\hline Nasal barbel length & 25.8 & $15.0-28.9$ & $24.2 \pm 5.7$ \\
\hline Outer mental barbel length & 76.7 & $53.9-82.4$ & $67.4 \pm 8.4$ \\
\hline Inner mental barbel length & 44.5 & $37.5-47.5$ & $42.3 \pm 2.9$ \\
\hline Body width at cleithrum & 41.5 & $44.0-50.0$ & $47.5 \pm 2.2$ \\
\hline Interneural shield length & 29.9 & $26.7-32.6$ & $30.7 \pm 2.0$ \\
\hline Supraoccipital spine length & 16.0 & $13.6-16.6$ & $15.6 \pm 1.0$ \\
\hline Snout to supra occipital spine length & 109.5 & $107.6-120.9$ & $114.1 \pm 5.0$ \\
\hline
\end{tabular}




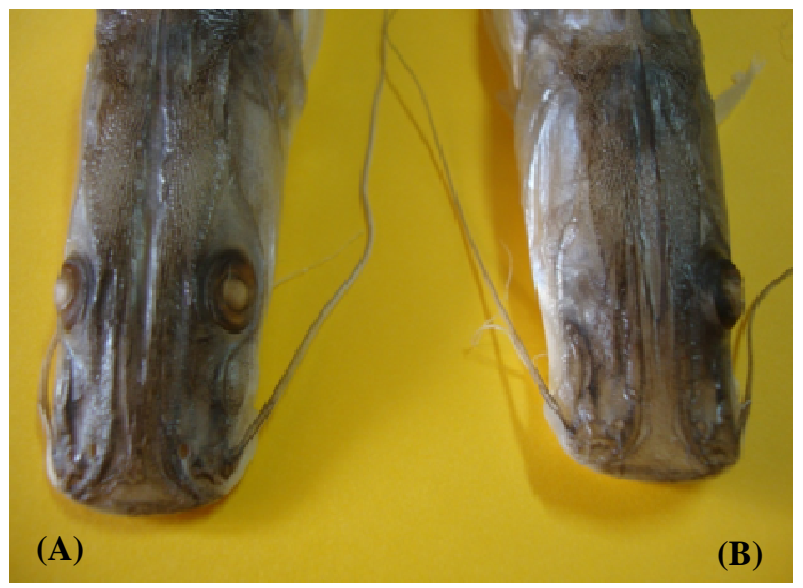

Fig. 1. Comparison of normal specimen (A) with abnormal specimen $(B)$.

sponsible for occurrence of anopthalmia in fish. Anophthalmia either can be heritable or can be caused by environmental disturbances (Tave and Handwerker, 1998). Tave et al. (2011) observed gross abnormalities in tilapia pertaining to eye which were non-heritable and possibly produced by pathogen, heat shock or chemicals. Symptom of anopthalmia was also observed in carps when dissolved oxygen concentration decreases to $25 \%$ of the saturation level (Anonymous, 1996). Occurrence of unilateral and bilateral anopthalmia in fish embryos exposed to insecticides has also been reported (Weis and Weis, 1976). No sign of injury or damage was observed on the side of the missing eye of the collected abnormal specimen of $S$. seenghala. On the contrary, the place was slightly depressed and covered with thin scales (Fig. 2).

Fowler (1970) and Barlow (1961) reviewed that lower count of some meristic characters in fishes may be due to environmental differences. While comparing the morphological features of the abnormal specimen with the normal specimens, no differences in the meristic count was found. However, some variation in the morphometric features of the abnormal fish was observed. The proportionate pre-pectoral length of the abnormal specimen was higher $(28.5 \mathrm{~mm})$ as compared to that of the healthy specimens $(23.8-26.5 \mathrm{~mm})$. Similarly, body depth at pectoral fin base was also found to be higher in the abnormal specimen $(12.0 \mathrm{~mm})$ compared to that of the normal specimens $(8.9-9.9 \mathrm{~mm})$. The body width at cleithrum was higher in case of normal specimens $(44.0-50.0 \mathrm{~mm})$ as compared to abnormal specimen $(41.5 \mathrm{~mm})$. The proportionate length of dorsal fin base $(15.0 \mathrm{~mm})$ and pelvic fin length $(15.5 \mathrm{~mm})$ of the abnormal specimen was found to be slightly higher than the normal specimens $(12.2-14.1 \mathrm{~mm}$ and $11.1-14.7 \mathrm{~mm}$, respectively). On the contrary, the dorsal to adipose distance of the abnormal specimen $(12.8 \mathrm{~mm})$ was slightly lower as compared to the normal specimens $(13.7-16.7 \mathrm{~mm})$. Also, the distance between urino-genital openings and anal fin base was more in case of the abnormal specimen $(14.0 \mathrm{~mm})$ than

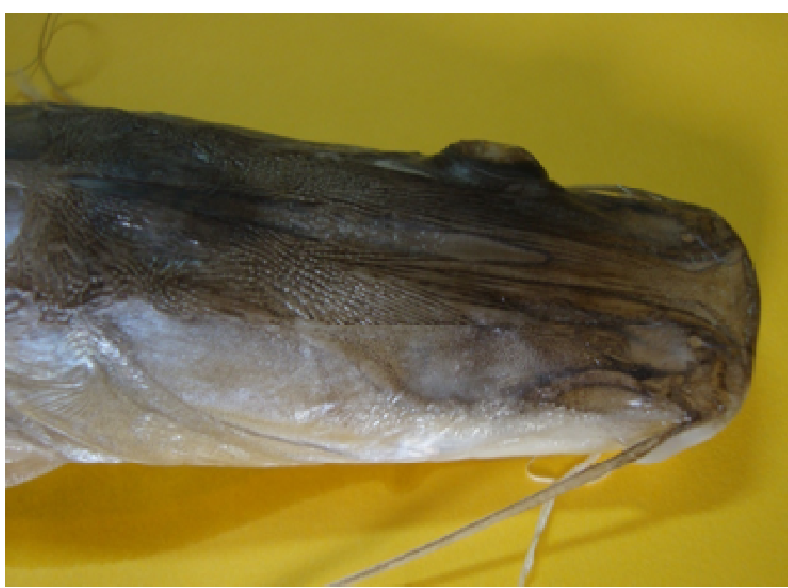

Fig. 2. Site of eye of abnormal specimen covered with scale.

that of the normal specimens $(10.9-12.4 \mathrm{~mm})$.

Occurrence of different body component ratios of abnormal specimens of Mahisefed (Rutilus frissikutum) populations from Caspian sea have been reported by Naserizadeh et al., (2013), for which they proposed diverse abiotic (diverse pollutants) and biotic (inbreeding) parameters as affecting factors. Subba (1999) observed deviation in the length of dorsal fin height in proportion to standard length in case of African catfish pointing pollution as the reason for abnormalities. Similarly, deviation of body component ratio in an abnormal species of Bagarius bagarius due to developmental error was also reported by Subba (2008). Bussing (1966) found high degree of intraspecific variation in the proportionate length among the population of Pygmidium striatum from Costa Rica. The author, however, did not report any valid reason for such variation.

Although, the causes of variation in the morphometric features cannot be ascertained, environmental stress due to fluctuation in dissolved oxygen and carbon dioxide content coupled with presence of harmful pollutants may be a responsible factor. Since, the river runs adjacent to the metropolitan city, it receives huge pollution load through heavy sewage discharge, industrial effluents and urban runoff daily, as such the chances of extreme fluctuation in dissolved oxygen and carbon dioxide content exists. Turner and Farley (1971), Anonymous (1996), Martens et al. (2006) and Barman et al. (2014) in their respective investigation on Striped bass, Carps, Atlantic salmon and Mystus tengara reported the case of anopthalmia due to high fluctuations in dissolved oxygen and carbon dioxide content. Moreover, as inland ferry services are prominent in the river; the chances of the river getting polluted by oil spill are high. Similar effect of pollutant causing anophthalmia has been documented by Subba (1999) and Kruitwagen et al. (2006) in the African catfish and mudskipper respectively. As many factors are simultaneously intermixing with the soil and water of the river, it is difficult to pin point a particular factor for 
the cause of malformation. For this, a detailed study on the soil and water quality parameter as well as the health status of the river is required to obtain a better understanding on the causes responsible for such abnormalities and to ascertain the effect of harmful pollutants. Further, as the collected abnormal specimen was a juvenile, there is a possibility that the morphometric variation may not remain the same, if it was allowed to grow. Klumpp and Von Westernhagen (1995) opined that the number of malformed fish that survive usually decreases with development and few individuals with abnormalities survive until adult stages. Similarly, Nakayama et al. (2005) in their experiment found that only few medaka embryos that developed anophthalmia following maternal exposure to tributyltin hatched successfully, and none survived for more than a few days. Hence, it is possible that the single anophthalmic $S$. seenghala found in the present investigation may have malformed during development.

\section{Conclusion}

The absence of eye does not seem to have induced any significant change in the gross morphological characters of the fish compared to that of normal specimens. Since few samples were studied for comparison, alleviating the size of representative sample may give a better analysis of change in body component ratio. Further studies on the soil and water quality of the water body would not only give a precise preview on the health status but also help in validating the causes of malformation.

\section{ACKNOWLEDGEMENTS}

First author is grateful to the Director, ICAR - NRC on Pig for granting study leave and to the staff of FRM division, ICAR-CIFE, Mumbai for providing necessary help and support during the course of investigation.

\section{REFERENCES}

Anonymous (1996). Department of Water Affairs and Forestry, South African Water Quality Guidelines $\left(2^{\text {nd }}\right.$ edition). Volume 6: Agricultural Waste Use: Aquaculture, pp 170.

Barlow, G.W. (1961). Causes and significance of morphological variation in fishes. Syst. Zool., 10: 105-117.

Barman, J., Jaiswar, A.K., Chakraborty, S.K., Jahgeerdar, S. and Lakra, W.S. (2014). A record of Anopthalmia in Mystus tengara (Hamilton, 1822) from Assam. Journal of Applied and Natural Science, 6 (2): 589-593.

Bussing, William A. (1966). New species and new records of Costa Rican freshwater fishes with a tentative list of species. Rev. Biol. Trop., 14 (2): $205-249$.

Cahu, C., Infante, J.Z. and Takeuchi, T. (2003). Nutritional components affecting skeletal development in fish larvae. Aquaculture, 227: $245-258$.

Cunningham, M.E., Markle, D.F., Watral, V.G., Kent, M.L. and Curtis, L.R. (2005). Patterns of fish deformities and their associates with trematode cysts in The Williamette
River. Oregon. Env. Biol. Fishes, 73: 9 - 19.

Ferraris, C.J. Jr. and Runge, K.E. (1999). Revision of the South Asian Bagrid catfish genus Sperata, with the description of a new species from Myanmar. Proc. Calif. Acad. Sci., 51 (10): 397-424.

Fowler, J.A. (1970). Control of vertebral number in teleosts an embryological problem. Q, Rev. Biol., 45: $148-167$.

Gupta, S.C., Dutta, S.P.S. and Sharma, N. (2000). A report on some morphological deformities in silver carp $\mathrm{Hy}$ pophthalmicthys molitrix (Valenciennes) inhabiting aquatic environment of Jammu $(\mathrm{J} \& \mathrm{~K})$. Himalayan $J$. Env. and Zool., 14: 25 - 30.

Jesu Arockia Raj, A., Seetharaman, S. and Haniffa, M.A. (2004). Skeletal deformities in a few freshwater fishes from Bhavani river, Tamil Nadu. Zoo's Print Journal, 19 (9): 1628 - 1629.

Klumpp, D.W. and Von Westernhagen, H. (1995). Biological effects of pollutants in Australian tropical coastal waters: embryonic malformations and chromosomal aberrations in developing fish eggs. Marine Pollut. Bull., 30: 158 - 165.

Kruitwagen, G., Hecht, H., Pratap, H.B. andWendelaarBonga, S.E. (2006). Changes in morphology and growth of the mudskipper (Periophthalmus argentilineatus) associated with coastal pollution. Mar. Biol., 149: 201-211. DOI 10.1007/s00227-005-0178-z.

Lin Sun, P.L., Hawkins, W.E., Overstreet, R.M. and Brown Peterson, N.J. (2009). Morphological deformities as biomarkers in fish from contaminated rivers in Taiwan. Int. J. Environ. Res. Public Health, 6: 2307-2331.

Martens, L.G., Witten, P.E., Fivelstad, S., Huysseume, A., Savedreid, B., Vikessa, V. and Obach, A. (2006). Impact of high carbon dioxide on Atlantic salmon smolts (Salmo salar L.): effect on fish performance, vertebral composition and structure .Aquacult, 61 (1): 80 - 88.

Nagarajan, M. (2012). Spinal deformities in wild population of Mystus montanus. Int. J. Biological Technology, 3 (3): $23-24$.

Nakayama, K., Oshima, Y., Nagafuchi, K., Hano, T., Shimasaki, Y. and Nakayamaj, K. (2005). Early-life-stage toxicity in offspring from exposed parent medaka, Oryzias latipes, to mixtures of tributyltin and polychlorinated biphenyls. Environ. Toxicol. Chem., 24: 591 -596 .

Naserizadeh, M., Safari, O. and Nematollahi, M.A. (2013). First report on the abnormality among body component ratios in the caught Caspian Sea Mahisefid (Rutilus frissikutum, Kamensky, 1901). Turk. J. Fish. Aquat. Sci., 13: $383-387$.

Roberts, T.R. (1992). Revision of the striped catfishes of Thailand misidentified as Mystus vittatus, with descriptions of two new species (Pisces: Bagridae). Ichthyol. Explor. Freshw., 3: $77-88$.

Saha, H. and Saha, R.K. (2013). Occurrence of innate morphological deformities in fishes of Tripura, North East India-A possible case of Inbreeding. World J. Fish \& Marine Sci., 5(4): 405 408. DOI:10. $\backslash 5829$ idosi. wjfms. 2013.05.04.7392.

Sarkar, H.L. and Kapoor, B.G. (1956). Deformities in some Indian catfishes. J. Zool. Soc., India, 8: 157 - 164.

Subba, B.R. (1999). Multiple abnormalities in African catfish. J. Inst. Agric. Anim. Sci.,19 - 20: 187 - 191.

Subba, B.R. (2008). Abnormality in Bagarius bagarius (Ham.) (Cypriniformes: Sisoridae) from Nepal. Our Nature, 6: 26-29. 
Tave, D. and Handwerker, T. (1998). Anophthalmia: A nonheritable eye deformity in Oreochromis mossambicus. Ribarstvo, 56 (4): 125 - 130.

Tave, D., Jo, Jae-Yoon.and Kim, D.S. (2011). Gross abnormalities in Tilapia. Fish Aquat. Sci., 14 (2): 148 - 160. DOI 10.1007/s00227-005-0178-z.

Turner, J.L. and Farley, T.C. (1971). Effects of temperature, salinity and dissolved oxygen on the survival of striped bass eggs and larvae. Calif. Fish Game, 57: 268 - 273.

Weis, J.S. and Weis, P. (1976). Optical malformations induced by insecticides in embryos of the Atlantic silverside Menidia menidia. Fish. Bull., 74 (1): 208 - 211.

Weis, J.S. and Weis, P. (1989). Effects of environmental pollutants on early fish development. Aquat. Sci., 1: 45-73. 